Lohmann, G. and D. G. Pearce (2010). "Conceptualizing and operationalizing nodal tourism functions." Journal of Transport Geography 18(2): 266-275.

\title{
Conceptualizing and Operationalizing Nodal Tourism Functions
}

\section{Introduction}

Destination competitiveness has emerged as a significant theme over the past decade as competition among places seeking to develop tourism has intensified. This has led to a search for those factors that enhance the comparative and competitive advantage of different places (Cracolici and Nijkamp, 2006; Crouch and Ritchie, 1999; Dwyer et al., 2000; Enright and Newton, 2004). The emphasis to date has been on analyzing the factor endowments that provide a comparative advantage and on identifying those attributes, predominantly managerial, that influence the ability to use these endowments - the competitive advantage (Crouch and Ritchie, 1999). In stressing competitiveness, the nature of destinations - the other half of the concept - often appears to be assumed or taken for granted in these studies. Framke (2002:93) notes that although destination is one of the most frequently used concepts in tourism, 'different actors in the tourism industry and among tourism researchers use it very differently'. He asserts (p.93) 'there appears to be certain systematic self-contradictions in its use: the destination as a narrative, as an attraction, as a geographical unit, as a marketing object, as a place where tourism happens'. Moreover, other literatures, particularly those dealing with the geography of tourism and transport, the analysis of tourist flows and tourism planning, refer to different sorts of tourism places other than destinations; these include origins, gateways, hubs, stopovers and various sub-categorizations of these (Dredge, 1999; Forer and Pearce, 1984; Lew and McKercher, 2002; O'Kelly and Miller, 1994; Oppermann, 1995; Pearce, 1995a, 1995b, 
Lohmann, G. and D. G. Pearce (2010). "Conceptualizing and operationalizing nodal tourism functions." Journal of Transport Geography 18(2): 266-275.

2001). Further complexity arises out of the possibility that places may have multiple roles, being in varying degrees origins, destinations, gateways, hubs and stopovers (Pearce, 1981, 1995a, 2001). Furthermore, strategic planning and management may enable the transformation of one dominant role into another, for example, the development of gateways and hubs into major destinations as in the cases of Singapore and Dubai (Bowen, 2000; Lohmann et al., 2009; Low and Heng, 1997).

Given these different perspectives and possibilities, it may therefore be more appropriate henceforth to speak of place competitiveness rather than destination competitiveness. Developing such competitiveness requires a better understanding of the various and multiple tourism functions that places may have. This in turn requires a clearer conceptualization of these functions and, in particular, a practical means of operationalizing them. The objective of this paper then is to present a methodology for identifying and measuring the tourism functions of specific places and to illustrate it with reference to a comparative analysis of ferry passengers traveling between two tourist nodes in New Zealand: Wellington and Picton. While the methodology has been developed with and illustrated by these New Zealand examples it has a more general application to places in other settings and might be used to develop a broader understanding of nodal tourism functions and their implications for place competitiveness.

As much international tourism in New Zealand is characterized by a large degree of circuit travel (Forer, 2005), the country provides a very appropriate context in which to explore these issues. If particular places are seen as nodes in a national tourism network or 
Lohmann, G. and D. G. Pearce (2010). "Conceptualizing and operationalizing nodal tourism functions." Journal of Transport Geography 18(2): 266-275.

system, then the high level of mobility associated with the movement of international visitors, and, to a lesser degree, domestic tourists throughout New Zealand means that different nodes are likely to exhibit a range of functions. Moreover, the various nodes are in competition with each other in the sense that unless the overall length of stay grows, increasing the demand at one place on the circuit will inevitably be at the expense of another. In this situation, better understanding of the patterns of demand associated with the specific functions of particular places will assist in their marketing and management.

The next section of the paper reviews the conceptualization of the relevant nodal functions. The methodology by which the key functions are operationalized is then outlined before the findings are presented and conclusions are drawn.

\section{Conceptualizing Nodal Functions}

The terminology associated with various nodal functions is rather variable. As Framke (2002) has observed in the case of destinations, many concepts are often used rather loosely or generally; usage may vary from context to context and discipline to discipline. In other cases, concepts such as hubs may acquire a particular technical meaning (Dennis, 1994). Most models of tourist space and tourist travel are based on an underlying origin-linkage-destination system (Pearce, 1995b). The end components - the origins and destinations - are rarely explicated at any length. More attention is often given to the linkage functions and researchers focusing on flows and itineraries have developed increasingly complex classifications of such functions (Forer and Pearce, 1984; Lew and McKercher, 2002). 
Lohmann, G. and D. G. Pearce (2010). "Conceptualizing and operationalizing nodal tourism functions." Journal of Transport Geography 18(2): 266-275.

\subsection{Origins}

Origins are the markets or source areas of visitors, their place of permanent residence. Various models classify the flows of tourists emanating from the origins in terms of volume, duration of trip and distance traveled so that a series of concentric rings of decreasing travel intensity might be identified (Pearce, 1995b). Use of a range of demand data can reveal major market functions for places otherwise thought of primarily as destinations, for example Madrid (Pearce and Priestley, 1998).

\subsection{Destinations}

In contrast, destinations might be thought of geographically as the places which constitute the object of the trip, where all or a major part of the visit is played out. Transport analysts refer to 'true destinations' as the endpoint of the trip (Fleming and Hayuth, 1994) though it should be noted in the case of touring, travel itself may be the main activity with a number of places being visited (Pearce, 1995b). Framke (2002) provides an interesting elaboration, offering a business oriented and sociological comparison of what constitutes a destination based on four sets of factors: geographical limitation, destination content, cooperation and the tourist. For instance, from the first perspective, he argues, tourists are seen as economic consumers or segments; from the second, as experience seeking social actors and consumers. In terms of content, the sociological research underlines the dynamic process shaping the place where tourism happens; the businessoriented studies emphasize the agglomeration of core and peripheral attractions and 
Lohmann, G. and D. G. Pearce (2010). "Conceptualizing and operationalizing nodal tourism functions." Journal of Transport Geography 18(2): 266-275.

services, a point also stressed in the destination competitiveness literature outlined above (Crouch and Ritchie, 1999; Enright and Newton, 2004).

\subsection{Gateways}

Gateways in a general sense are seen as major entry/exit points into or out of a national or regional system (Pearce, 2001). Gateways not only link other nodes within a national or regional network but also serve to link one network to another (Burghardt, 1971). As Zurick (1992) observes, gateways can exist at a range of scales. Several writers have considered the gateway or portal function of communities adjacent to national parks (Ewert, 1996; Mules, 2005; Yuan and Christensen, 1994). For others, gateway cities are synonymous with large metropolitan centers (Bowden, 2006; Caruana and Simmons, 1995; Ley and Murphy, 2001; Page, 2001; Short et al., 2000). In their study of MICE tourism, for instance, Mistilis and Dwyer (1999:448) define gateways simply as 'a capital city in a state or territory...; non-gateway is any other locality outside a gateway...' Transport analysts, however, tend to give a more theoretical account of gateway functions. Fleming and Hayuth (1994) consider the role of gateways and other transportation hubs in terms of centrality and intermediacy, the latter being used (p.4) to describe 'locations between important origins and destinations'. Proximity - the attribute of being close to a market or set of productive resources - is another factor included by Fleming and Hayuth, according to whom one of the clearest examples is gateway proximity to tourist attractions. O'Connor (1995) uses these ideas of centrality, 
Lohmann, G. and D. G. Pearce (2010). "Conceptualizing and operationalizing nodal tourism functions." Journal of Transport Geography 18(2): 266-275.

intermediacy and proximity to examine changes in airport development in Southeast Asia.

\subsection{Hubs}

Traditionally used in a fairly general sense to mean a place which functions as a crossroads or any large airport or airline operating base, the concept of hubs has come to assume a more technical meaning as the result of changes in airline practices and relates to their transfer functions within a wider network (Dennis, 1994). O’Kelly and Miller (1994:31) define a hub as 'a major sorting or switching centre in a many-to-many distribution system...the key idea is that the flow between a set of origin-destination cities passes through one or more hubs en route to the final destination'. Fleming and Hayuth (1994) use the terms centrality and intermediacy as spatial qualities that enhance the traffic levels of transportation hubs, and hence indicate that they are places strategically located within transportation systems.

\subsection{Stopovers}

The concept of stopovers is less developed than the other functions and derives from analyses of touring or circuit travel. As the name suggests, stopovers refer to places which serve as way points between destinations or function as secondary destinations on longer circuits (Pearce, 1981; Pearce and Elliott, 1983).

\subsection{Multiple functions}

Other terms are one indication that places may have multiple functions. Caves and Gosling (1999), for instance, use the term 'gateway hubs' to refer to 
Lohmann, G. and D. G. Pearce (2010). "Conceptualizing and operationalizing nodal tourism functions." Journal of Transport Geography 18(2): 266-275.

gateways on the periphery of Europe which provide onward services to secondary centers. From 'an overnight destination perspective', Lew and McKercher (2002:614) speak of 'hub destinations' as 'any place that is visited more than once in a multiple destination itinerary' and use the terms 'gateway destination' and 'egress destination' to refer to the first and last places visited on multiple destination itineraries. Here the functions are defined with respect to their position in such itineraries and in the last two cases are simply the entry and exit points. In his model of urban tourism spaces, Pearce (1981) explicitly incorporated the idea that larger urban centers in particular may have multiple nodal functions due to their size, infrastructure and place in the urban hierarchy. He later developed the practical implications of multiple nodal functions with regard to tourism planning (Pearce, 1995a).

Despite this recognition of the existence of different types of nodal functions, there has been little empirical research that has sought to measure their relative importance in particular places. Pearce and Elliott (1983) developed the Trip Index, a relative measure of time spent, and compared the travel patterns of visitors to an urban gateway and national park in New Zealand. This technique has also been used to segment visitors to South Carolina (Uysal and McDonald, 1989) and to Malaysia (Oppermann, 1995) as well as to analyze spatial and seasonal variations in travel within the United States (Uysal et al., 1994). At a higher level, Lew and McKercher (2002) examined the relative location of Hong Kong in international itineraries. 
Lohmann, G. and D. G. Pearce (2010). "Conceptualizing and operationalizing nodal tourism functions." Journal of Transport Geography 18(2): 266-275.

Considerable scope exists then to operationalize nodal tourism functions and to analyze more closely the multiple roles that specific places play in larger national and regional networks. In particular, there is a need to distinguish clearly between functions and measure their relative importance. The next section outlines the methodology by which this was achieved in the New Zealand study.

\section{Methodology}

Wellington and Picton were chosen for this study as they represent two linked but contrasting nodes that a priori would exhibit multiple functions yet at the same time be expected to differ in the relative importance of these, thereby providing ample scope to measure and compare their nodal functions. Located respectively at the south of the North Island and north of the South Island and connected by the inter-island ferry services (Figure 1), Wellington and Picton typify the eccentric location at the end of a catchment area characteristic of many gateways (Burghardt, 1971). Wellington's central location within the country was the main reason why the seat of government was transferred there in 1865. As the nation's capital, the city has a significant amount of business travel and in recent years has attracted a growing number of tourists through the development of a vibrant arts and café culture, the successful promotion of events, an active marketing campaign and the opening of the National Museum of New Zealand - Te Papa Tongarewa which draws a million visitors a year (Doorne, 2000; Pearce, 2007; Pearce and Tan, 2004). With a city population of 164000 and a regional population twice that size, Wellington also attracts a large number of visits from friends and relatives and acts as a major source 
Lohmann, G. and D. G. Pearce (2010). "Conceptualizing and operationalizing nodal tourism functions." Journal of Transport Geography 18(2): 266-275.

of domestic tourists. In 2004, 4.5 million visitors spent 8.3 million nights in the city (Pearce, 2007). In contrast, Picton is a small town of 4,000 residents, a railhead located at the end of Queen Charlotte Sound and a popular summer destination for visitors who enjoy a range of water-based activities, walking and mountain biking. Visitors to Picton are estimated to reach a daily peak of 20000 in the height of summer.

Wellington also is an important air hub with the busiest airport in New Zealand in terms of scheduled domestic flights but it ranks a distant third to Auckland and Christchurch in terms of international arrivals (Pearce, 2007). Picton has a very small airport with flights to the capital operated by 12 -seat propeller aircrafts. The major airline in the country, Air New Zealand, offers flights out of nearby airports such as Blenheim and Nelson. As the results of the survey conducted with ferry passengers show, the main reason for passengers taking the ferry is the ability to take their vehicle with them (46.8\%) and price (23.3\%). Airfares across Cook Strait were at least twice the price of a walk-on passenger fare on the ferries.

The focus of this study, however, is on the passengers using the ferry service that links the two nodes. Two ferry companies operate regular sailings which each year carry an estimated 1265000 passengers, 253000 vehicles and over 2.5 million tons of freight per annum across Cook Strait (Marlborough Economic Development Trust, 2001). The study thus adopts a demand side perspective to examine the nodal functions of Wellington and Picton based on a survey of inter-island ferry passengers. While such an approach does not include all visitors to Wellington and 
Lohmann, G. and D. G. Pearce (2010). "Conceptualizing and operationalizing nodal tourism functions." Journal of Transport Geography 18(2): 266-275.

Picton, and thus does not provide a comprehensive picture of their nodal functions, it does enable comparable data to be collected in the same way and using the same sample frame from the respondents visiting or passing through both places.

The survey was conducted onboard Cook Strait ferries between August 2003 and January 2004. A total of 35 trips (18 northbound and 17 southbound) were made on different days of the week, during one long weekend and throughout low and high tourist seasons. Other factors were also taken into consideration to ensure the sample would be representative, such as the different ferry services (The Lynx, The Interislander and Bluebridge) operating at that stage and their time and place of departure. A total of 1,076 self-administered questionnaires were completed, representing $85 \%$ of the questionnaires distributed. The questions concentrated on the passengers' travel patterns and profile characteristics. The survey data were then analyzed using SPSS. The central thrust of the analysis reported here was to identify the various nodal functions of Wellington and Picton and to establish the relative importance of these for three key segments: international passengers, those living within the regional catchment and other domestic travelers. This required operationalizing the concepts discussed above using a mix of variables included for this purpose in the survey.

Pearce and Elliott's (1983) Trip Index (TI) relates the number of nights spent in a particular destination (Dn) to the total number of nights spent on the whole trip $(\mathrm{Tn})$, according to the formula $\mathrm{TI}=(\mathrm{Dn}) * 100 /(\mathrm{Tn})$. The values recorded can then be classified along a spectrum from 0 or no nights spent, representing a transit stop or 
Lohmann, G. and D. G. Pearce (2010). "Conceptualizing and operationalizing nodal tourism functions." Journal of Transport Geography 18(2): 266-275.

day visit, to 100 , where that place is the sole destination. Intermediate values represent short and medium stopovers or main destinations. The Trip Index is a comparatively simple and practical measure and has proved a useful complementary segmentation variable but by itself it has limitations as the reasons underlying a visit to any place have to be assumed. Likewise, use of the relative location of a place in a multiple destination itinerary, as proposed by Lew and McKercher (2002), also has its limitations for identifying gateways when those gateways may occur in the middle of a trip rather than at the beginning or end of it, as with inter-island travel in the present case.

To overcome the limitations used in previous studies and to develop a more refined means of operationalizing selected concepts, a combination of length of stay and main reason for visiting the node was adopted (Figure 2). Length of stay is important as travelers staying some time in a node are more likely to engage with the tourism industry and treat it as a destination, either primary or secondary. Three possibilities for the number of nights spent in the node were considered: travelers that do not stay overnight, those that spend one night and those that stay two or more nights. In terms of purpose of visit the focus was on determining whether or not the main reason for going to the node was to make a ferry connection, that is, the node was being used principally as a gateway to enter or leave the North or South Island.

On this basis four classes of visitor were identified. Gateway travelers were defined as those travelers that do not stay overnight in the node and whose main reason for going there is the transport connection. There are two situations where travelers are 
Lohmann, G. and D. G. Pearce (2010). "Conceptualizing and operationalizing nodal tourism functions." Journal of Transport Geography 18(2): 266-275.

classified as stopover visitors. In the first case, the traveler is not staying overnight but has another important reason for going to the node apart from the transport connection $\left(\mathrm{SV}_{1}\right)$. In the second, a traveler is spending only one night in the node but is staying more than one night away from home $(\mathrm{TI} \neq 100)$ and has a main reason for visit other than the transport connection $\left(\mathrm{SV}_{2}\right)$. Stopover visitors can be characterized by the fact that they have some sort of interaction with the node apart from the gateway function. Overnight gateway visitors consist of those travelers who are spending only one night in the node, they are away from home more than one night $(\mathrm{TI} \neq 100)$, and have the transport connection as the main reason for visit. Fourthly, passengers staying two or more nights are classified as destination tourists (DT) regardless of their main reason for going to the node. Even though some travelers may state that their main reason for going there is the transport connection, the fact that they are staying two or more nights is an indication that there are other important reasons for traveling there and interacting with the locality. An exception would be the case of travelers whose travel plans were disrupted, for example by cancellation or delay of a crossing. Even in this situation, travelers who end up staying two or more nights in the node increase their chances of engaging in tourist activities and visiting tourist attractions, hence their classification as destination tourists $\left(\mathrm{DT}_{1}\right)$. Travelers staying a single night in the node are also included among destination tourists $\left(\mathrm{DT}_{2}\right)$ when this is their sole destination $(\mathrm{TI}=100)$. A fifth category - origin- consists of passengers residing in Wellington or Picton who were beginning their journey in their home port. No category of hub visitors was considered as the ferry services only run between the two ports in question. 
Lohmann, G. and D. G. Pearce (2010). "Conceptualizing and operationalizing nodal tourism functions." Journal of Transport Geography 18(2): 266-275.

The different nodal functions identified in this way were then analyzed by place of origin as it was anticipated that the functions played by Wellington and Picton would vary on this dimension (Janin, 1982). Ferry passengers originating in or close to the two ports would have less need to make a stopover before connecting with the ferry while also being more likely to already be familiar with those places and therefore less inclined to take advantage of their ferry crossing to make a visit. For the purposes of this analysis, the respondents were grouped into three categories:

- those originating within the immediate catchment of the ports of Wellington and Picton, defined as those living in the regions of Wellington, Wairarapa, Nelson and Marlborough (at that time these four regions were marketed overseas in a joint effort by their regional tourism organizations and key tourism and transportation industry members as the macro region of the Centre Stage of New Zealand - Figure $1)$

- domestic passengers from other parts of New Zealand;

- $\quad$ international passengers - the three major markets were the United Kingdom (29.5\%), Australia, (20.7\%) and the USA (10.2\%).

Just over $40 \%$ of the respondents were international passengers; the remainder were divided almost evenly between those coming from within the region and from other parts of New Zealand.

\section{Findings}


Lohmann, G. and D. G. Pearce (2010). "Conceptualizing and operationalizing nodal tourism functions." Journal of Transport Geography 18(2): 266-275.

Table 1 illustrates clearly the differences in the nodal functions of Wellington and Picton; the former has a more evenly distributed range of functions while the gateway role is dominant in Picton. The greater population of the capital is reflected in its importance as a source of passengers (17.4\%) while the diversity of attractions it offers accounts for almost a quarter of the respondents being classified as destination tourists. Nevertheless, the majority of passengers fall into one of the three transitory classes, with $26.8 \%$ using the city as a gateway. In contrast, two thirds of all passengers were using Picton solely as a gateway, its origin function was negligible $(0.8 \%)$ and only $7.8 \%$ there were classified as destination tourists.

Major differences are also seen in the way in which these functions vary by place of origin. In the case of Wellington, the origin function dominates for Centre Stage visitors $(62 \%)$ while about a third each of the international visitors are classified as destination tourists or stopover visitors. The other New Zealand passengers constitute an intermediate group, half of them are using Wellington as a gateway and only $20 \%$ are destination tourists. Reading the table vertically, international passengers constitute a higher proportion of the three categories which show a greater involvement with the city: destination tourists (56.6\%), stopover visitors (64.4\%) and overnight gateway visitors $(60.2 \%)$. Centre Stage visitors make up over half of all the gateway travelers and, by definition, all the origin respondents come from within the region. In contrast, the gateway function in Picton is dominant for all three groups, ranging from $61 \%$ for international visitors to $74 \%$ for other New Zealand passengers. International passengers are the largest group of destination tourists in Picton (45.7\%), but relative to their overall share, Centre 
Lohmann, G. and D. G. Pearce (2010). "Conceptualizing and operationalizing nodal tourism functions." Journal of Transport Geography 18(2): 266-275.

Stage visitors are over-represented $(38.3 \%)$ - this reflects the greater flow of Wellingtonians across Cook Strait compared to Nelson and Marlborough residents visiting the capital.

The importance of these variations in nodal functions to tourism in Wellington and Picton is demonstrated by Tables 2 and 3 which show the activities undertaken and attractions visited by the different segments. In both places participation rates are much higher amongst destination tourists and stopover visitors than for overnight gateway visitors and, especially, gateway travelers who have relatively little engagement with Wellington or Picton. Likewise, it is only the destination tourists and overnight gateway visitors who are generating demand for accommodation. Consequently, in terms of developing tourism in these places, the question arises as to what extent and in what ways might the nodal functions be modified, for example, what scope exists to convert gateway travelers into stopover visitors or destination tourists?

To explore this issue ferry passengers were asked if more information about both Wellington and Picton or a special deal combining the ferry crossing and accommodation in one of these places would make them change their length of stay in either of these places. As information search plays a key role in trip decision-making (Gursoy and McCleary, 2004), the aim here was to examine if passengers were simply not staying longer because they were unaware of what was on offer. Additionally, as travel is generally subject to budgetary considerations, the second question examined whether there was any type of financial incentive that would make them increase their stay (no details were sought on any 
Lohmann, G. and D. G. Pearce (2010). "Conceptualizing and operationalizing nodal tourism functions." Journal of Transport Geography 18(2): 266-275.

such incentives respondents may already have been offered but no such practices were evident at the time of survey). Actual behavior, of course, may not match stated intentions and the following results must therefore be regarded as indicative.

Table 5 shows that the vast majority of passengers would not have changed the length of their visit to Wellington had more information been made available to them at the time of booking. This is especially the case with gateway travelers $(86.4 \%)$ who are the segment less inclined to stay longer; they appear to have little interest other than making their ferry connection. However, a reasonable proportion of overnight gateway visitors (21.2\%) and stopover visitors $(23.1 \%)$ indicated that more information about Wellington would have induced them to lengthen their stay. Fifteen per cent of destination visitors, the segment with already the greatest level of engagement, also indicated they would lengthen their stay had they had more information. Table 5 also shows that across all four nodal segments it is the international passengers who would be most interested in extending their stay had they had more information about the capital city: overnight gateway travelers (33.8\%), stopover visitors (31.6\%), destination travelers (19\%), and gateway travelers (14.3\%). New Zealand passengers appear to be less influenced by information provision. It seems that they believe that they are already familiar with the place and have sufficient information to decide whether or not to extend their stay in the capital.

Respondents indicate that a special deal would potentially have a greater impact on their decision to stay longer than information provision (Table 5). This difference is especially noticeable in the case of domestic visitors from outside the Centre Stage region. 
Lohmann, G. and D. G. Pearce (2010). "Conceptualizing and operationalizing nodal tourism functions." Journal of Transport Geography 18(2): 266-275.

For example, while none of the domestic overnight gateway visitors would potentially stay longer than planned in Wellington if they had more information (Table 4), a special deal would have induced $19.5 \%$ of them to stay longer. A similar pattern occurs with Centre Stage and other New Zealand passengers for all other nodal functions. In the case of gateway travelers, the decision to stay in Wellington due to a special deal would perhaps be an incentive to make them change from an overnight stopover somewhere else near Wellington, to more affordable accommodation in the capital city. Nevertheless, it is still the international passengers who are the most responsive group by origin, for example, over a third of the international overnight gateway visitors and stopover visitors indicated that a special deal would have induced them to extend their stay in Wellington. Overall, when considering the various nodal functions, it is once again travelers already staying in Wellington who seem to be more sensitive to a special deal than those not staying overnight. Gateway travelers intent on reaching their destination are less likely to be persuaded to stay overnight.

Similar patterns are found with regard to Picton, though the impact of providing more information and offering special deals is less marked there than in Wellington (Tables 6 and 7). Again, information provision would have a greater impact on increasing the length of stay of overnight gateway visitors (11.9\%) and stopover visitors (11.1\%) and the least on gateway travelers (5.3\%). In a small number of cases, increasing awareness about Picton would have the opposite effect, encouraging some passengers to shorten their stay (e.g. 3.4\% of overnight gateway visitors). Once more it is the international visitors across all four nodal functions who are the most likely to be influenced by greater information 
Lohmann, G. and D. G. Pearce (2010). "Conceptualizing and operationalizing nodal tourism functions." Journal of Transport Geography 18(2): 266-275.

provision, with very few Centre Stage or other New Zealand passengers modifying their plans. As in Wellington, offering a special deal is more likely to influence travel plans than information provision, especially amongst overnight gateway visitors and stopover visitors. International visitors across all four nodal functions are again the group most responsive to such an offer.

\section{Discussions and Conclusions}

This analysis has clearly shown from a demand perspective how tourism nodes may fulfill multiple functions. The term destination does not fully express the function Wellington and Picton play for ferry passengers. Nor are these places solely gateways. Rather, the segmentation of visitors combining length of stay, Trip Index values and purpose of visit (Figure 2) has revealed a more subtle set of functions which each place exhibits to a greater or lesser degree (Table 1). It is the complex of multiple functions which distinguishes one place from the other: Wellington, the larger metropolitan centre and capital, is characterized by a more even distribution of functions; Picton, the smaller node, has a dominant gateway function but nevertheless still attracts some destination tourists and stopover visitors. Moreover, the relative functions of the two places were shown to vary systematically by place of origin. In Wellington, for example, international visitors made up a higher proportion of destination tourists and stopover and overnight gateway visitors, Centre Stage visitors made up half of all gateway travelers and other New Zealand visitors constituted an intermediate group. This is a reflection of such factors as location and broader travel patterns. 
Lohmann, G. and D. G. Pearce (2010). "Conceptualizing and operationalizing nodal tourism functions." Journal of Transport Geography 18(2): 266-275.

The crucial link between the nodal functions and engagement with the local tourism industry has been illustrated by the varying rates of participation in attractions and activities reported by the different nodal function segments (Tables 2 and 3). This link in turn raised the issue of whether it would be possible to modify the nodal functions through such marketing activities as providing more information about the nodes and offering special deals combining transport and accommodation. The results depicted in Tables 4 to 7 suggest this would be a challenging undertaking but might be worth pursuing if a more targeted approach based on functional segmentation were adopted. In particular, gateway travelers whose main reason for going to Wellington or Picton was to make an inter-island connection showed relatively little inclination to change their plans. Greater potential exists to lengthen the stay of stopover visitors or overnight gateway travelers, moreso in the case of Wellington than Picton. The results in Tables 4 to 7 also suggest that such effort be directed in particular at increasing the length of stay of international visitors, particularly those traveling independently, as these show the greatest propensity to have their travel plans modified. While regional tourism organizations and industry providers might make more information available to this group, the challenges of developing and marketing special ferry and accommodation packages should not, however, be underestimated.

Given the nature of circuit travel in New Zealand, any modification of the nodal functions of Wellington and Picton would inevitably impact on patterns of visitation in other nodes unless total demand were increased. In other words, encouraging ferry passengers to spend more time in Wellington and Picton would most likely result in a reduction of time spent elsewhere on the trips being undertaken thus highlighting the nature 
Lohmann, G. and D. G. Pearce (2010). "Conceptualizing and operationalizing nodal tourism functions." Journal of Transport Geography 18(2): 266-275.

of place competitiveness. While this would benefit those two nodes, it would in turn require competing places to reassess their functions.

More generally, this study has demonstrated how a more nuanced approach to the analysis of nodal functions might complement existing approaches to tourism competitiveness and shown the value of thinking beyond destinations to consider the various and multiple functions places might play. The approach has also shown how it is possible to operationalize many of the nodal concepts hitherto used rather loosely in the literature and illustrated the practical applications of such operationalization. The combination of the purpose of visit information with the length of stay data, both absolute and relative, has been especially useful. Further refinement of the concepts and techniques would result from their application to nodes in other contexts and systems. Comparative studies would be especially useful in this regard. While the focus here has been on one set of visitors - ferry passengers - future studies might also be extended to include all visitors to particular nodes, not just those travelling by one mode of transport as this would enable a more complete picture of the node to emerge and also allow analyses of any inter-modal variations in functions. Attention might also be directed at segmenting those visitors by other variables, such as travel arrangements, to examine what effect independent or packaged travel has on nodal tourism functions.

\section{Acknowledgements}


Lohmann, G. and D. G. Pearce (2010). "Conceptualizing and operationalizing nodal tourism functions." Journal of Transport Geography 18(2): 266-275.

This research was made possible through a CAPES Foundation scholarship (Brazilian

Ministry of Education) received by Dr Gui Lohmann in order to undertake his $\mathrm{PhD}$ at

Victoria University of Wellington.

\section{List of References}

Bowden, J., 2006. A Logistic Regression Analysis of the Cross-Cultural Differences of the Main Destination Choices of International Tourists in China's Main Gateway Cities. Tourism Geographies, 8(4), 403 428.

Bowen, J., 2000. Airline Hubs in Southeast Asia: National Economic Development and Nodal Accessibility. Journal of Transport Geography, 8(1), 25-41.

Burghardt, A. F., 1971. A Hypothesis About Gateway Cities. Annals of the Association of American Geographers, 61(2), 269-85.

Caruana, V., Simmons, C., 1995. The Role of Traffic Growth and Capital Investment from 1918-82 in the Development of Manchester Airport as an International Gateway. Journal of Transport Geography, 3(3), 199-219.

Caves, R. E., Gosling, G. D., 1999. Strategic Airport Planning. Oxford, Pergamon.

Cracolici, M. F., Nijkamp, P., 2006. Competition among Tourist Destinations: An Application of Data Envelopment Analysis to Italian Provinces. In: Giaoutzi, M., Nijkamp, P. (Eds.) Tourism and Regional Development: New Pathways. Hampshire, Ashgate.

Crouch, G. I., Ritchie, J. R. B., 1999. Tourism, Competitiveness, and Societal Prosperity. Journal of Business Research, 44(3), 137-152.

Dennis, N., 1994. Airline Hub Operations in Europe. Journal of Transport Geography, 2(4), 219-233.

Doorne, S. M., 2000. Tourism the Capital City. In: McConchie, J., Winchester, D., Willis, R. (Eds.) Dynamic Wellington: A Contemporary Synthesis and Explanation of Wellington. Wellington, Victoria University of Wellington.

Dredge, D., 1999. Destination Place Planning and Design. Annals of Tourism Research, 26(4), 772-791.

Dwyer, L., Forsyth, P., Rao, P., 2000. The Price Competitiveness of Travel and Tourism: A Comparison of 19 Destinations. Tourism Management, 21(1), 9-22.

Enright, M. J., Newton, J., 2004. Tourism Destination Competitiveness: A Quantitative Approach. Tourism Management, 25(6), 777-788.

Ewert, A. W., 1996. Gateways to Adventure Tourism: The Economic Impacts of Mountaineering on One Portal Community. Tourism Analysis, 1(1), 59-63.

Fleming, D. K., Hayuth, Y., 1994. Spatial Characteristics of Transportation Hubs: Centrality and Intermediacy. Journal of Transport Geography, 2(1), 3-18.

Forer, P., 2005. Tourist Flows and Dynamic Geographies: Applying Gi Science to Understanding Tourist Movement and Impact. In: Simmons, D. G., Fairweather, J. R. (Eds.) Understanding the Tourism Host-Guest Encounter in New Zealand: Foundations for Adaptive Planning and Management. Christchurch, EOS Ecology.

Forer, P. C., Pearce, D. G., 1984. Spatial Patterns of Package Tourism in New Zealand. New Zealand Geographer, 40(1), 34-42.

Framke, W., 2002. The Destination as a Concept: A Discussion of the Business-Related Perspective Versus the Socio-Cultural Approach in Tourism Theory. Scandinavian Journal of Hospitality and Tourism, 2(2), 92-108.

Gursoy, D., McCleary, K., 2004. An Integrative Model of Tourists' Information Search Behavior. Annals of Tourism Research, 31(2), 353-373. 
Lohmann, G. and D. G. Pearce (2010). "Conceptualizing and operationalizing nodal tourism functions." Journal of Transport Geography 18(2): 266-275.

Lew, A., McKercher, B., 2002. Trip Destinations, Gateways and Itineraries: The Example of Hong Kong. Tourism Management, 23(6), 609-621.

Ley, D., Murphy, P., 2001. Immigration in Gateways Cities: Sydney and Vancouver in Comparative Perspective. Progress in Planning, 55(3), 119-194.

Lohmann, G., Albers, S., Koch, B., Pavlovich, K., 2009. From Hub to Tourist Destination - an Explorative Study of Singapore and Dubai's Aviation-Based Transformation. Journal of Air Transport Management, 15(4).

Low, L., Heng, T. M., 1997. Singapore: Development of Gateway Tourism. In: Go, F. M., Jenkins, C. L. (Eds.) Tourism and Economic Development in Asia and Australasia. London, Cassell.

Marlborough Economic Development Trust, 2001. Marlborough Today: An Analysis of the Current Economic Base of the Region. Blenheim, Marlborough Economic Development Trust.

Mistilis, N., Dwyer, L., 1999. Tourism Gateways and Regional Economies: The Distributional Impacts of Mice. International Journal of Tourism Research, 1(6), 441-457.

Mules, T., 2005. Economic Impacts of National Park Tourism on Gateway Communities: The Case of Kosciuszko National Park. Tourism Economics, 11(2), 247-259.

O'Connor, K., 1995. Airport Development in Southeast Asia. Journal of Transport Geography, 3(4), 269-279.

O'Kelly, M. E., Miller, H. J., 1994. The Hub Network Design Problem: A Review and Synthesis. Journal of Transport Geography, 2(1), 31-40.

Oppermann, M., 1995. A Model of Travel Itineraries. Journal of Travel Research, 33(4), 57-61.

Page, S., 2001. Gateways, Hubs and Transport Interconnections in Southeast Asia: Implications for Tourism Development in the Twenty-First Century. In: Teo, P., Chang, T. C., Ho, K. C. (Eds.) Interconnected Worlds: Tourism in Southeast Asia. Oxford, Pergamon.

Pearce, D. G., 1981. L'éspace Touristique De La Grande Ville: Éléments De Synthèse Et Application À Christchurch (Nouvelle-Zélande). L'Espace Géographique, 10(3), 207-213.

Pearce, D. G., 1995a. Planning for Tourism in the Nineties: An Integrated, Dynamic, Multi-Scale Approach. In: Butler, R. W., Pearce, D. G. (Eds.) Change in Tourism: People, Places, Processes. London, Routledge.

Pearce, D. G., 1995b. Tourism Today: A Geographical Analysis. Harlow \& New York, Wiley.

Pearce, D. G., 2001. Towards a Regional Analysis of Tourism in Southeast Asia. In: Teo, P., Chang, T. C., Ho, K. C. (Eds.) Interconnected Worlds: Tourism in Southeast Asia. Oxford, Pergamon.

Pearce, D. G., 2007. Capital City Tourism: Perspectives from Wellington. Journal of Travel and Tourism Marketing, 22(3/4), 7-20.

Pearce, D. G., Elliott, J. M. C., 1983. The Trip Index. Journal of Travel Research, 22(1), 6-9.

Pearce, D. G., Priestley, G. K., 1998. Tourism in Spain: A Spatial Analysis and Synthesis. Tourism Analysis, 2(3/4), 185-205.

Pearce, D. G., Tan, R., 2004. Distribution Channels for Heritage and Cultural Tourism in New Zealand. Asia Pacific Journal of Tourism Research, 9(3), 225-237.

Short, J. R., Breitbach, C., Buckmand, S., Essex, J., 2000. From World Cities to Gateway Cities: Extending the Boundaries of Globalization Theory. City, 4(3), 317-340.

Uysal, M., Fesenmaier, D. R., O'Leary, J. T., 1994. Geographic and Seasonal Variation in the Concentration of Travel in the United States. Journal of Travel Research, 32(3), 61-64.

Uysal, M., McDonald, C. D., 1989. Visitor Segmentation by Trip Index. Journal of Travel Research, 27(3), $38-42$.

Yuan, M. S., Christensen, N. A., 1994. Wildland-Influenced Economic Impacts of Nonresident Travel on Portal Communities: The Case of Missoula, Montana. Journal of Travel Research, 32(4), 26-31.

Zurick, D. N., 1992. Adventure Travel and Sustainable Tourism in the Peripheral Economy of Nepal. Annals of the Association of American Geographers, 82(4), 608-628. 
Lohmann, G. and D. G. Pearce (2010). "Conceptualizing and operationalizing nodal tourism functions." Journal of Transport Geography 18(2): 266-275.

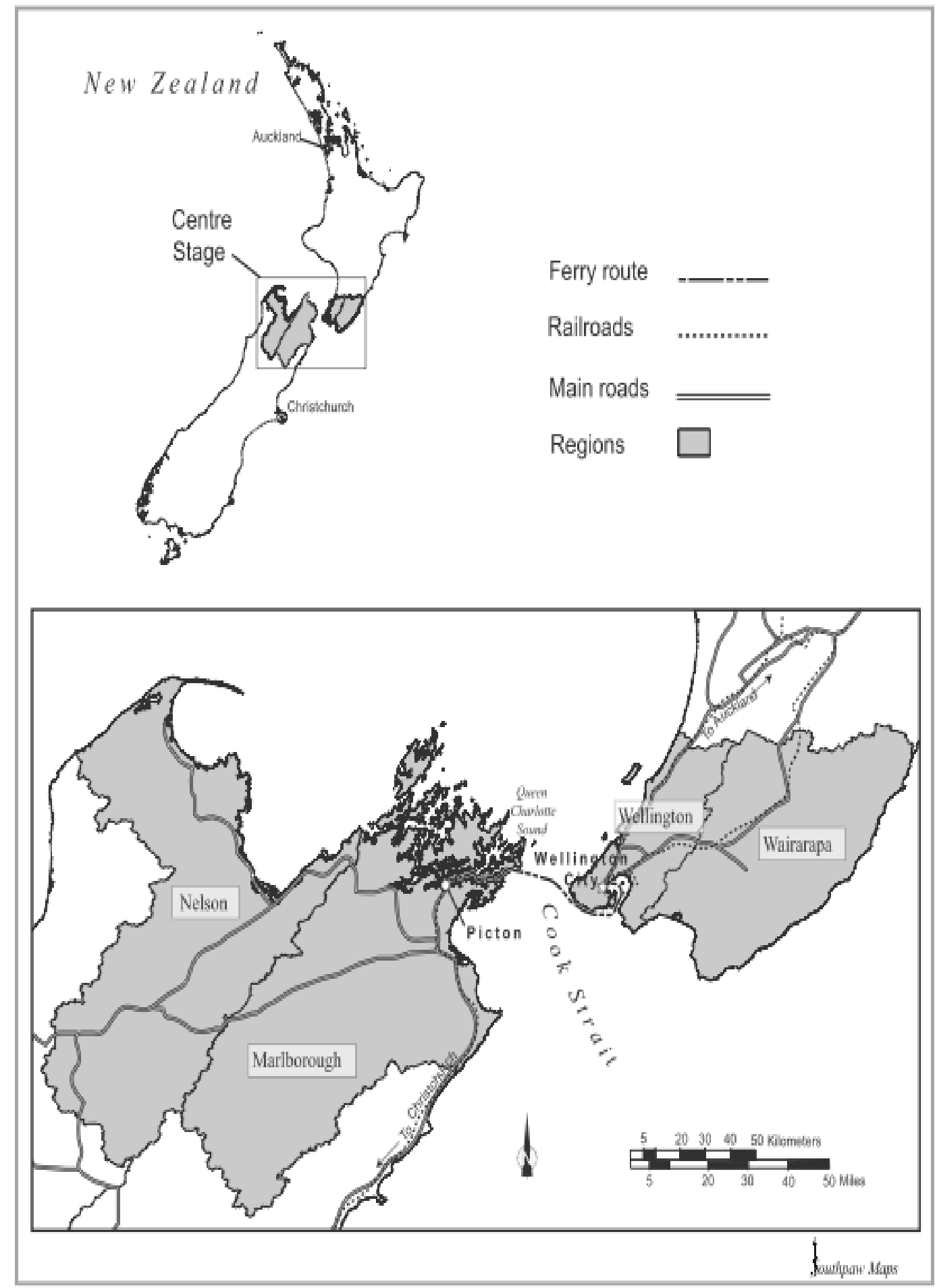

Figure 1 Wellington and Picton: location and ferry connections. 
Lohmann, G. and D. G. Pearce (2010). "Conceptualizing and operationalizing nodal tourism functions." Journal of Transport Geography 18(2): 266-275.

How many nights is the passenger spending in the node before/after taking the ferry?

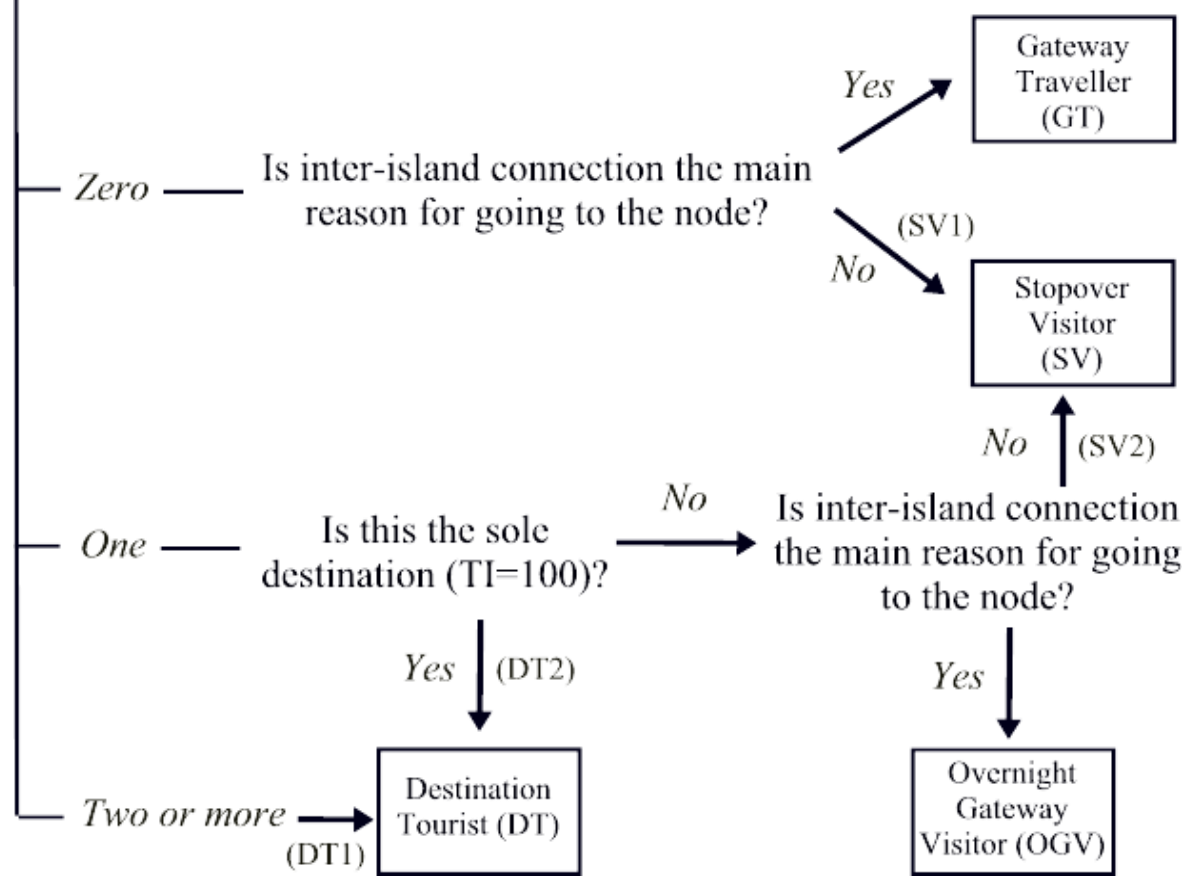

Figure 2. Operationalizing nodal functions. 
Lohmann, G. and D. G. Pearce (2010). "Conceptualizing and operationalizing nodal tourism functions." Journal of Transport Geography 18(2): 266-275.

Table 1: Nodal functions by place of origin

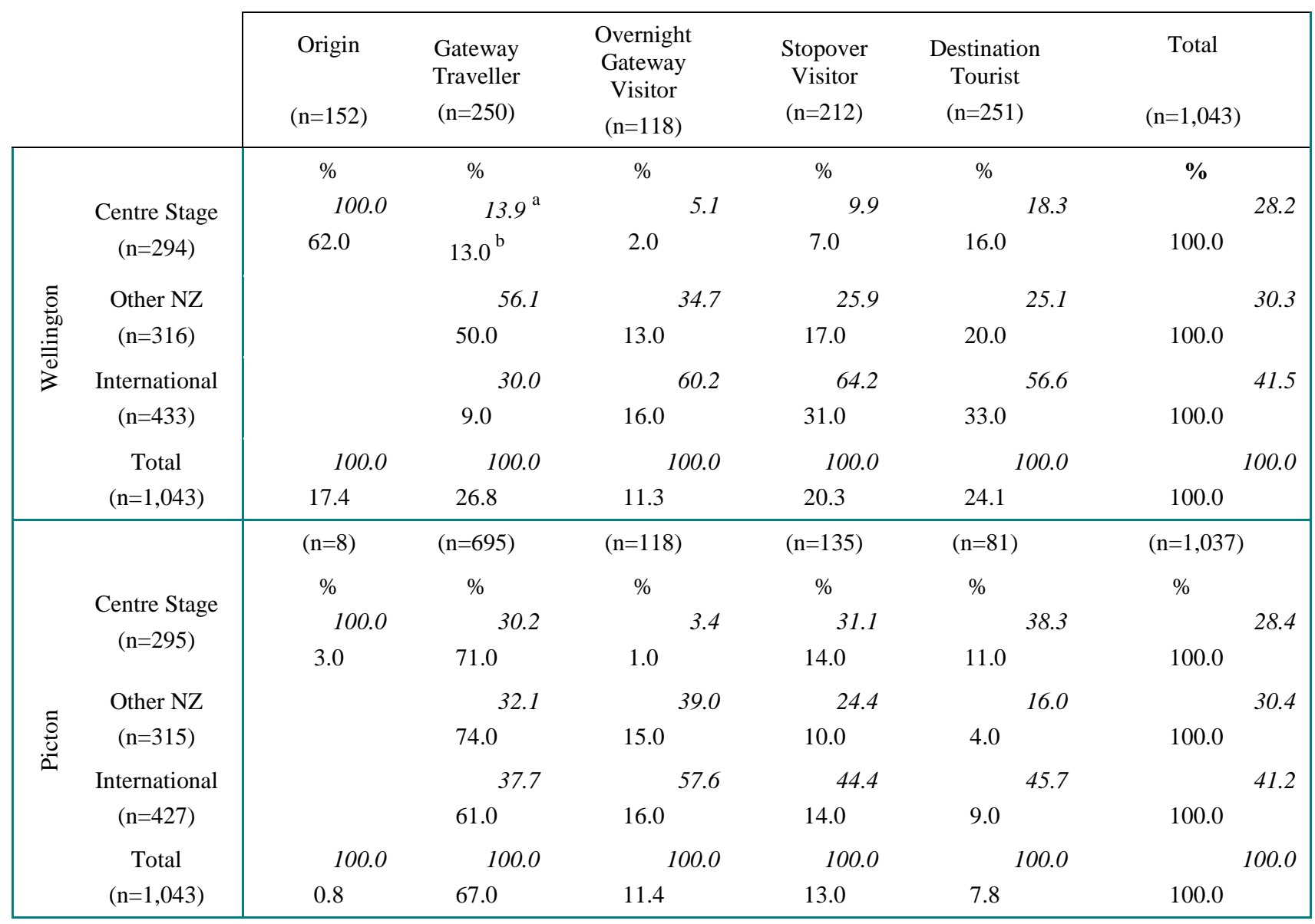

${ }^{\mathrm{a}}$ Column \%

${ }^{\mathrm{b}}$ Row $\%$ 
Lohmann, G. and D. G. Pearce (2010). "Conceptualizing and operationalizing nodal tourism functions." Journal of Transport Geography 18(2): 266-275.

Table 2: Activities undertaken and attractions visited in Wellington by nodal function

\begin{tabular}{|l|c|c|c|c|}
\cline { 2 - 5 } \multicolumn{1}{c|}{} & Gateway Travelers & Overnight Gateway Visitor & Stopover Visitors & Destination Tourists \\
\cline { 2 - 5 } & $(\mathrm{n}=280)$ & $(\mathrm{n}=118)$ & $(\mathrm{n}=212)$ & $(\mathrm{n}=251)$ \\
\hline Walk in the city & $\%$ & $\%$ & $\%$ & $\%$ \\
Shopping & 13.2 & 53.4 & 52.4 & 70.9 \\
Eating out / restaurant & 8.9 & 29.7 & 30.6 & 65.3 \\
Te Papa Museum & 7.5 & 39.0 & 35.4 & 61.0 \\
Café & 11.8 & 33.1 & 42.0 & 59.0 \\
Bar & 11.4 & 37.3 & 43.9 & 33.4 \\
Botanic Garden & 2.9 & 16.1 & 23.6 & 36.7 \\
Cable Car & 2.5 & 14.4 & 16.5 & 30.7 \\
General/tour sightseeing & 3.2 & 21.2 & 18.4 & 30.3 \\
Parliament & 2.5 & 11.9 & 19.3 & 22.7 \\
Scenic drive & 2.1 & 12.7 & 17.4 & 21.9 \\
Cultural events & 3.2 & 12.7 & 8.5 & 15.5 \\
City Gallery Wellington & 1.1 & 0.8 & 4.2 & 12.7 \\
Bush walk & 0.7 & 0.8 & 3.8 & 12.4 \\
Museum of City \& Sea & 0.4 & 0.8 & 8.5 & 1.6 \\
\hline
\end{tabular}

Nota bene: multiple responses 
Lohmann, G. and D. G. Pearce (2010). "Conceptualizing and operationalizing nodal tourism functions." Journal of Transport Geography 18(2): 266-275.

Table 3: Activities undertaken and attractions visited in Picton by nodal function

\begin{tabular}{|c|c|c|c|c|}
\hline \multirow{2}{*}{ Activities / Attractions } & Gateway Travelers & $\begin{array}{c}\text { Overnight Gateway } \\
\text { Visitors }\end{array}$ & Stopover Visitors & Destination Tourists \\
\hline & $(\mathrm{n}=695)$ & $(n=118)$ & $(\mathrm{n}=135)$ & $(\mathrm{n}=81)$ \\
\hline & $\%$ & $\%$ & $\%$ & $\%$ \\
\hline Walk in town & 19.7 & 56.8 & 41.5 & 60.5 \\
\hline Eating out & 14.5 & 33.1 & 32.6 & 43.2 \\
\hline General sightseeing & 10.2 & 33.9 & 20.7 & 43.2 \\
\hline Sailing & 3.3 & 7.6 & 9.6 & 34.6 \\
\hline Mini golf & 1.4 & 5.1 & 4.4 & 29.6 \\
\hline Picton museum & 5.5 & 12.7 & 8.1 & 28.4 \\
\hline Queen Charlotte Track & 2.7 & 5.9 & 9.6 & 19.8 \\
\hline Scenic boat cruise & 0.9 & 2.5 & 3.0 & 17.3 \\
\hline Trekking / tramping & 1.4 & 3.4 & 5.9 & 16.0 \\
\hline Water taxi & 0.7 & 3.4 & 8.1 & 11.1 \\
\hline $\begin{array}{l}\text { Aquarium of the } \\
\text { Marlborough Sounds }\end{array}$ & 1.6 & 0.8 & 4.4 & 8.6 \\
\hline Beach & 0.7 & 1.7 & 3.7 & 8.6 \\
\hline Bush walk & 1.0 & & 1.5 & 6.2 \\
\hline
\end{tabular}

Nota bene: multiple responses 
Lohmann, G. and D. G. Pearce (2010). "Conceptualizing and operationalizing nodal tourism functions." Journal of Transport Geography 18(2): 266-275.

Table 4 Change of plans if passenger had more information about Wellington

\begin{tabular}{|c|c|c|c|c|c|c|c|c|c|c|c|c|c|c|c|c|}
\hline & \multicolumn{4}{|c|}{ Gateway Travelers } & \multicolumn{4}{|c|}{ Overnight Gateway Visitors } & \multicolumn{4}{|c|}{ Stopover Visitors } & \multicolumn{4}{|c|}{ Destination Tourists } \\
\hline & $\begin{array}{c}\text { Centre } \\
\text { Stage } \\
(n=39)\end{array}$ & $\begin{array}{c}\text { Other } \\
\text { NZ } \\
(n=157)\end{array}$ & $\begin{array}{c}\text { Int'l } \\
(n=84)\end{array}$ & $\begin{array}{l}\text { Total } \\
(\mathrm{n}=280)\end{array}$ & $\begin{array}{l}\text { Centre } \\
\text { Stage } \\
(\mathrm{n}=6)\end{array}$ & $\begin{array}{c}\text { Other } \\
\mathrm{NZ} \\
(\mathrm{n}=41)\end{array}$ & $\begin{array}{l}\text { Int'l } \\
(n=71)\end{array}$ & $\begin{array}{c}\text { Total } \\
(\mathrm{n}=118)\end{array}$ & $\begin{array}{l}\text { Centre } \\
\text { Stage } \\
(\mathrm{n}=21)\end{array}$ & $\begin{array}{c}\text { Other } \\
\mathrm{NZ} \\
(\mathrm{n}=55)\end{array}$ & $\begin{array}{c}\text { Int'l } \\
(n=136)\end{array}$ & $\begin{array}{c}\text { Total } \\
(\mathrm{n}=212)\end{array}$ & $\begin{array}{c}\text { Centre } \\
\text { Stage } \\
(\mathrm{n}=46)\end{array}$ & $\begin{array}{c}\text { Other } \\
\text { NZ } \\
(n=63)\end{array}$ & $\begin{array}{c}\text { Int'l } \\
(n=142)\end{array}$ & $\begin{array}{c}\text { Total } \\
(n=251)\end{array}$ \\
\hline & $\%$ & $\%$ & $\%$ & $\%$ & $\%$ & $\%$ & $\%$ & $\%$ & $\%$ & $\%$ & $\%$ & $\%$ & $\%$ & $\%$ & $\%$ & $\%$ \\
\hline No changes made & 97.4 & 93.6 & 67.9 & 86.4 & 66.7 & 97.6 & 60.6 & 73.7 & 90.5 & 92.7 & 63.2 & 73.6 & 93.5 & 82.5 & 71.8 & 78.5 \\
\hline Stay longer & 2.6 & 2.5 & 14.3 & 6.1 & 16.7 & & 33.8 & 21.2 & 9.5 & 7.3 & 31.6 & 23.1 & 6.5 & 12.7 & 19.0 & 15.1 \\
\hline Stay shorter & & & 2.4 & 0.7 & & & & & & & & & & 1.6 & 1.4 & 1.2 \\
\hline No response & & 3.9 & 15.4 & 6.8 & 16.6 & 2.4 & 5.6 & 5.1 & & & 5.2 & 3.3 & & 3.2 & 7.8 & 5.2 \\
\hline Total & 100.0 & 100.0 & 100.0 & 100.0 & 100.0 & 100.0 & 100.0 & 100.0 & 100.0 & 100.0 & 100.0 & 100.0 & 100.0 & 100.0 & 100.0 & 100.0 \\
\hline
\end{tabular}

Table 5 Change of plans if passenger was offered a special deal in Wellington

\begin{tabular}{|c|c|c|c|c|c|c|c|c|c|c|c|c|c|c|c|c|}
\hline & \multicolumn{4}{|c|}{ Gateway Travelers } & \multicolumn{4}{|c|}{ Overnight Gateway Visitors } & \multicolumn{4}{|c|}{ Stopover Visitors } & \multicolumn{4}{|c|}{ Destination Tourists } \\
\hline & $\begin{array}{l}\text { Centre } \\
\text { Stage } \\
(\mathrm{n}=39)\end{array}$ & $\begin{array}{c}\text { Other } \\
\text { NZ } \\
(n=157)\end{array}$ & $\begin{array}{c}\text { Int'l } \\
(n=84)\end{array}$ & $\begin{array}{c}\text { Total } \\
(\mathrm{n}=280)\end{array}$ & $\begin{array}{l}\text { Centre } \\
\text { Stage } \\
(n=6)\end{array}$ & $\begin{array}{c}\text { Other } \\
\text { NZ } \\
(n=41)\end{array}$ & $\begin{array}{c}\text { Int'l } \\
(\mathrm{n}=71)\end{array}$ & $\begin{array}{c}\text { Total } \\
(\mathrm{n}=118)\end{array}$ & $\begin{array}{l}\text { Centre } \\
\text { Stage } \\
(n=21)\end{array}$ & $\begin{array}{c}\text { Other } \\
\text { NZ } \\
(\mathrm{n}=55)\end{array}$ & $\begin{array}{c}\text { Int'l } \\
(\mathrm{n}=136)\end{array}$ & $\begin{array}{c}\text { Total } \\
(n=212)\end{array}$ & $\begin{array}{c}\text { Centre } \\
\text { Stage } \\
(n=46)\end{array}$ & $\begin{array}{c}\text { Other } \\
\text { NZ } \\
(n=63)\end{array}$ & $\begin{array}{c}\text { Int'l } \\
(\mathrm{n}=142)\end{array}$ & $\begin{array}{c}\text { Total } \\
(\mathrm{n}=251)\end{array}$ \\
\hline & $\%$ & $\%$ & $\%$ & $\%$ & $\%$ & $\%$ & $\%$ & $\%$ & $\%$ & $\%$ & $\%$ & $\%$ & $\%$ & $\%$ & $\%$ & $\%$ \\
\hline No changes made & 84.6 & 72.6 & 63.1 & 71.4 & 66.7 & 78.0 & 56.3 & 64.4 & 76.2 & 74.5 & 60.3 & 65.6 & 82.6 & 68.3 & 58.5 & 65.3 \\
\hline Stay longer & 10.3 & 19.1 & 22.6 & 18.9 & 16.7 & 19.5 & 36.6 & 29.7 & 19.0 & 20.0 & 35.3 & 29.7 & 17.4 & 25.4 & 28.2 & 25.5 \\
\hline Stay shorter & & & 1.2 & 0.4 & & & 1.4 & 0.8 & & & & & & & 2.8 & 1.6 \\
\hline No response & 5.1 & 8.3 & 13.1 & 9.3 & 16.7 & 2.5 & 5.7 & 5.1 & 4.8 & 5.5 & 4.4 & 4.7 & & 6.3 & 10.5 & 7.6 \\
\hline Total & 100.0 & 100.0 & 100.0 & 100.0 & 100.0 & 100.0 & 100.0 & 100.0 & 100.0 & 100.0 & 100.0 & 100.0 & 100.0 & 100.0 & 100.0 & 100.0 \\
\hline
\end{tabular}


Lohmann, G. and D. G. Pearce (2010). "Conceptualizing and operationalizing nodal tourism functions." Journal of Transport Geography 18(2): 266-275.

Table 6 Change of plans if passenger had more information in Picton

\begin{tabular}{|c|c|c|c|c|c|c|c|c|c|c|c|c|c|c|c|c|}
\hline & \multicolumn{4}{|c|}{ Gateway Travelers } & \multicolumn{4}{|c|}{ Overnight Gateway Visitors } & \multicolumn{4}{|c|}{ Stopover Visitors } & \multicolumn{4}{|c|}{ Destination Tourists } \\
\hline & $\begin{array}{l}\text { Centre } \\
\text { Stage } \\
(\mathrm{n}=210)\end{array}$ & $\begin{array}{l}\text { Other NZ } \\
(\mathrm{n}=223)\end{array}$ & $\begin{array}{c}\text { Int'l } \\
(\mathrm{n}=262)\end{array}$ & $\begin{array}{c}\text { Total } \\
(\mathrm{n}=695)\end{array}$ & $\begin{array}{l}\text { Centre } \\
\text { Stage } \\
(\mathrm{n}=4)\end{array}$ & $\begin{array}{c}\text { Other NZ } \\
(\mathrm{n}=46)\end{array}$ & $\begin{array}{c}\text { Int'l } \\
(\mathrm{n}=68)\end{array}$ & $\begin{array}{l}\text { Total } \\
(\mathrm{n}=118)\end{array}$ & $\begin{array}{l}\text { Centre } \\
\text { Stage } \\
(\mathrm{n}=42)\end{array}$ & $\begin{array}{c}\text { Other NZ } \\
(n=33)\end{array}$ & $\begin{array}{c}\text { Int'l } \\
(\mathrm{n}=60)\end{array}$ & $\begin{array}{l}\text { Total } \\
(\mathrm{n}=135)\end{array}$ & $\begin{array}{l}\text { Centre } \\
\text { Stage } \\
(\mathrm{n}=31)\end{array}$ & $\begin{array}{c}\text { Other } \\
\mathrm{NZ} \\
(\mathrm{n}=13)\end{array}$ & $\begin{array}{c}\text { Int'l } \\
(n=37)\end{array}$ & $\begin{array}{l}\text { Total } \\
(\mathrm{n}=81)\end{array}$ \\
\hline & $\%$ & $\%$ & $\%$ & $\%$ & $\%$ & $\%$ & $\%$ & $\%$ & $\%$ & $\%$ & $\%$ & $\%$ & $\%$ & $\%$ & $\%$ & $\%$ \\
\hline No changes made & 91.9 & 91.9 & 66.8 & 82.4 & 100 & 91.3 & 66.2 & 77.1 & 90.5 & 93.9 & 60.0 & 77.8 & 96.8 & 76.9 & 78.4 & 85.2 \\
\hline Stay longer & 1.9 & 4.0 & 9.2 & 5.3 & & 4.3 & 17.6 & 11.9 & 4.8 & 6.1 & 18.3 & 11.1 & & & 13.5 & 6.2 \\
\hline Stay shorter & 1.0 & & 0.8 & 0.6 & & 4.3 & 2.9 & 3.4 & & & & & 3.2 & & 2.7 & 2.5 \\
\hline Did not answer & 5.2 & 4.1 & 23.2 & 11.7 & & & 13.2 & 7.6 & 4.8 & & 21.7 & 11.1 & & 23.1 & 5.4 & 6.2 \\
\hline Total & 100.0 & 100.0 & 100.0 & 100.0 & 100.0 & 100.0 & 100.0 & 100.0 & 100.0 & 100.0 & 100.0 & 100.0 & 100.0 & 100.0 & 100.0 & 100.0 \\
\hline
\end{tabular}

Table 7 Change of plans if passenger was offered a special deal in Picton

\begin{tabular}{|c|c|c|c|c|c|c|c|c|c|c|c|c|c|c|c|c|}
\hline & \multicolumn{4}{|c|}{ Gateway Travelers } & \multicolumn{4}{|c|}{ Overnight Gateway Visitors } & \multicolumn{4}{|c|}{ Stopover Visitors } & \multicolumn{4}{|c|}{ Destination Tourists } \\
\hline & $\begin{array}{c}\text { Centre } \\
\text { Stage } \\
(\mathrm{n}=210)\end{array}$ & $\begin{array}{l}\text { Other NZ } \\
(n=223)\end{array}$ & $\begin{array}{c}\text { Int'l } \\
(\mathrm{n}=262)\end{array}$ & $\begin{array}{c}\text { Total } \\
(\mathrm{n}=695)\end{array}$ & $\begin{array}{l}\text { Centre } \\
\text { Stage } \\
(\mathrm{n}=4)\end{array}$ & $\begin{array}{c}\text { Other NZ } \\
(n=46)\end{array}$ & $\begin{array}{c}\text { Int'l } \\
(\mathrm{n}=68)\end{array}$ & $\begin{array}{c}\text { Total } \\
(\mathrm{n}=118) \\
\end{array}$ & $\begin{array}{c}\text { Centre } \\
\text { Stage } \\
(\mathrm{n}=42)\end{array}$ & $\begin{array}{c}\text { Other NZ } \\
(n=33)\end{array}$ & $\begin{array}{c}\text { Int'l } \\
(\mathrm{n}=60)\end{array}$ & $\begin{array}{c}\text { Total } \\
(\mathrm{n}=135)\end{array}$ & $\begin{array}{l}\text { Centre } \\
\text { Stage } \\
(\mathrm{n}=31)\end{array}$ & $\begin{array}{l}\text { Other NZ } \\
(n=13)\end{array}$ & $\begin{array}{c}\text { Int'l } \\
(\mathrm{n}=37)\end{array}$ & $\begin{array}{l}\text { Total } \\
(\mathrm{n}=81)\end{array}$ \\
\hline & $\%$ & $\%$ & $\%$ & $\%$ & $\%$ & $\%$ & $\%$ & $\%$ & $\%$ & $\%$ & $\%$ & $\%$ & $\%$ & $\%$ & $\%$ & $\%$ \\
\hline No changes made & 80.0 & 71.3 & 58.8 & 69.2 & 100 & 71.7 & 58.8 & 65.3 & 81.0 & 75.8 & 50.0 & 65.9 & 93.5 & 76.9 & 81.1 & 85.2 \\
\hline Stay longer & 9.5 & 11.2 & 13.0 & 11.4 & & 15.2 & 22.1 & 18.6 & 19.0 & 21.2 & 28.3 & 23.7 & 3.2 & 7.7 & 10.8 & 7.4 \\
\hline Stay shorter & 0.5 & & & 0.1 & & 4.3 & 1.5 & 2.5 & & & & & & & & \\
\hline Did not answer & 10.0 & 17.5 & 28.2 & 19.3 & & 8.7 & 17.6 & 13.6 & & 3.0 & 21.7 & 10.4 & 3.3 & 15.4 & 8.1 & 7.4 \\
\hline Total & 100.0 & 100.0 & 100.0 & 100.0 & 100.0 & 100.0 & 100.0 & 100.0 & 100.0 & 100.0 & 100.0 & 100.0 & 100.0 & 100.0 & 100.0 & 100.0 \\
\hline
\end{tabular}

